\title{
Strategi Nafkah Petani Perkotaan Pulau Kecil (Studi Kasus Kecamatan Leitimur Selatan Kota Ambon)
}

\author{
August Ernst Pattiselanno ${ }^{1}$, Edizon Jambormias ${ }^{2}$, Junianita Fridianova Sopamena ${ }^{3}$ \\ ${ }^{1}$ [Fakultas Pertanian, Universitas Pattimura, Poka Ambon, 97233, pattiselannoaugust@gmail.com ] \\ ${ }^{2}$ [Fakultas Pertanian, Universitas Pattimura, Poka Ambon, 97233, edy jambormias@ yahoo.com ] \\ ${ }_{3}^{3}$ Fakultas Pertanian, Universitas Pattimura, Poka Ambon, 97233, junianitasopamena@gmail.com ]
}

Diterima: 26 Oktober 2018

Direview: 21 Nopember 2018

Diterbitkan: 31 Desember 2018

Hak Cipta @ 2018 oleh Penulis (dkk) dan Jurnal Sosial Humaniora (JSH)

*This work is licensed under the Creative

Commons Attribution International License (CC

BY 4.0).

http://creativecommons.org/licenses/by/4.0/

\begin{abstract}
Subject Area : Economy (Ekonomi)
Abstract

Farmers who live along the coastal of a small island have various ways to fulfill their needs. The ways to fulfill their needs depend on various habits that have been carried out since a long time ago. The objective of this research is to analyze livelihood strategies designed by the societies in the small island. Research was located in South Leitumur District, Ambon City. The site of research was of two sub-districts, namely Hutumuri and Leahari. Sample of farmers were determined purposively from both sub-districts, resulting in 69 farmers, precisely 51 farmers in Hutumuri and 18 farmers in Leahari. Data were collected from depth interview and analyzed with simple tabulation accompanied with descriptive explanation. Result of the research indicated that there are three livelihood strategies designed by coastal communities in South Leitimur District, namely first, developing natural/farming resource potentials by increasing the quantity of commodities that have potential capability to satisfy daily necessities; second, developing natural/farming resource potentials in wider sense, which concerns with developing potentials of coastal area as fishing spot; and third developing human resource potentials by providing job opportunity out of farming and improving the existing skills owned by farmer household.
\end{abstract}

Keywords: city; farmers; livelihood strategies; small islands

\section{Latar Belakang}

Petani selama ini menjadi sumberdaya potensial dalam menyiapkan ketahanan pangan msayarakat. Dalam melakukan aktivitasnya, petani bergantung pada musim. Oleh karena itu, petani di Maluku khususnya di pulau kecil melakukan berbagai aktivitas ganda. Aktivitas yang umumnya berdampingan dengan aktivitas utama adalah sebagai nelayan. Nelayan menjadi pilihan pekerjaan mengingat sebagian besar petani pulau kecil, menetap di pesisir pantai sehingga berpeluang melakukan aktivitas di pesisir sebagai sumber pangan ataupun sumber pendapatan.

Secara umum, sebagian besar masyarakat di pulau kecil di Propinsi Maluku menggantungkan hidupnya dari sektor 
pertanian. Usaha tanaman perkebunan menjadi usaha tani unggulan yang berasal dari turun temurun. Jenis komoditi yang diusahakan antara lain, pala, cengkeh, dan kelapa. Komoditas lain yang berpotensi sebagai pangan keluarga adalah sayuran dan buahan.

Petani pesisir di Kota Ambon juga mengembangkan usaha tani komoditas perkebunan. Sebagai ibukota Provinsi Maluku, maka bisa kota sangat terasa dalam aktivitas masyarakat pesisir. Jumlah petani semakin tergerus, akibat berkurangnya lahan pertanian untuk memenuhi kebutuhan perumahan dan aktivitas perekonomian.

Data (Badan Pusat Statistik Kota Ambon, 2018) menunjukkan bahwa, jumlah penduduk Kota Ambon meningkat dari 354.464 jiwa di tahun 2012 menjadi 427.934 di tahun 2016, dengan laju pertumbuhan 3,96 persen. Tingkat kepadatan terendah ada di Kecamatan Leitimur Selatan. Hal ini mengindikasikan adanya aktivitas pertanian secara luas dan kontinu sebagai sumber pendapatan masyarakatnya. Namun, data potensi pertanian (di luar perikanan dan peternakan) belum tersedia. Oleh karena itu, dengan merujuk pada BPS Kota Ambon terlihat bahwa nilai produksi perikanan di Kecamatan Leitimur Selatan justru lebih rendah dibandingkan kecamatan yang lain di Kota Ambon. Sama halnya dengan populasi ternak di Kecamatan Leitumur Selatan, yang juga menempati urutan terendah di Kota Ambon.

Berdasarkan penjelasan tersebut, dapat dikatakan bahwa pemenuhan kebutuhan keluarga di Kecamatan Leitimur Selatan didominiasi oleh sektor pertanian terutama tanaman perkebunan, tanaman pangan, dan hortikultura (buah-buahan). Walaupun, data pendukungnya belum tersedia namun fakta di lapangan menunjukkan demikian. Oleh karena itu, menjadi penting untuk menganalisis sumber-sumber pendapatan keluarga beserta strategi yang dibangun setiap keluarga dalam memenuhi kebutuhan hidupnya. Strategi yang kemudian dalam pendekatan rumah tangga disebut sebagai strategi nafkah rumah tangga.

\section{Rumusan Masalah}

Hasil-hasil penelitian selama ini menunjukkan bahwa strategi nafkah rumah tangga sangat penting dalam mempertahankan keberlangsungan hidup melalui pemenuhan kebutuhan setiap rumah tangga. Studi-studi yang dilakukan, baik untuk konteks pulau besar maupun pulau kecil, menunjukkan petani menjalankan berbagai pilihan untuk memenuhi kebutuhan hidup rumah tangganya.

Strategi nafkah rumah tangga dikelompokkan menjadi tiga kategori yaitu, intensifikasi pertanian, ekstensifikasi nonpertanian, dan diversifikasi strategi nafkah berupa penerapan beragam pola nafkah dalam rumah tangga (Fridayanti \& Dharmawan, 2013; Niswah \& Adiwibowo, 2013; Dyah Ita Mardyaningsih, 2014; Saraswati \& Dharmawan, 2014 ). Hasil penelitian lain menjelaskan masyarakat memanfaatkan aset di bidang pertanian ketika terjadi krisis, serta diversifikasi dan migrasi merupakan pilihan strategi nafkah yang dilakukan masyarakat (Sembiring, 2014; Hidayati, Nurdin, Budiandrian, Attamimi, \& Rohayati, 2015). 
Penelitian yang berkaitan dengan resiliensi menjelaskan bahwa resiliensi nafkah petani dilakukan dengan meningkatkan strategi adaptasi berbasis ekonomi dan sosial, petani melakukan lebih dari satu strategi nafkah untuk mempertahankan kehidupannya, dan sebagian besar keluarga petani menjalankan strategi nafkah campuran (Widodo, 2009; Amalia, Dharmawan, \& Putri, 2015; Tridakusumah, Elfina, Mardiyaningsih, Pioke, \& Bumulo, 2015; Sugiharto, Hartoyo, \& Muflikhati, 2016). Penelitian terkini makin memperkuat kenyataan bahwa rumah tangga petani cenderung memanfaatkan modal alam dan modal finansial dalam memenuhi kebutuhan sehari-harinya ataupun membantunya dalam keadaan krisis (Budiyanti \& Dharmawan, 2018). Semua studi itu dilakukan dalam konteks wilayah pulau besar yang berpeluang berbeda dengan studi yang sama di pulau kecil.

Beberapa studi strategi nafkah yang dilakukan dalam konteks pulau kecil menghasilkan kesimpulan bahwa petani di pulau-pulau kecil cenderung berperan juga sebagai nelayan sesuai kondisi iklim yang berlangsung. Pertukaran peran antara petani dan nelayan, menunjukkan bahwa, aktivitas di pulau kecil terutama di pesisir sulit dipilah menjadi petani atau nelayan karena petani di pulau-pulau kecil cenderung melakukan strategi nafkah kolaborasi dengan memanfaatkan pertukaran peran antara petani dan nelayan dengan iklim sebagai faktor yang mendorong penyesuaian peran (Pattiselanno, Tuhumury, Wenno, \& Sopamena, 2017; Sopamena \& Pattiselanno, 2018).
Merujuk data BPS dan hasil-hasil penelitian tersebut, maka dapat dilihat bahwa Kecamatan Leitimur Selatan di Kota Ambon cenderung memanfaatkan aktivitas pertanian dan perikanan untuk memenuhi kebutuhan hidupnya. Pemenuhan kebutuhan hidup petani pesisir merupakan rangkaian strategi nafkah yang dijalankan secara kontinu, untuk memenuhi kebutuhan keluarganya. Oleh karena itu, permasalahan yang dikaji dalam penelitian ini yaitu bagaimana strategi nafkah masyarakat pesisir di Kecamatan Leitimur Selatan Kota Ambon?

\section{Tinjauan Literatur}

Scoones (1998) menjelaskan tiga bentuk strategi nafkah, yaitu strategi intensifikasi dan ekstensifikasi lahan pertanian (memanfaatkan sektor pertanian secara efektif dan efisien melalui penambahan input eksternal seperti teknologi dan tenaga kerja/intensifikasi, dan strategi nafkah dengan memperluas lahan garapan/ekstensifikasi); pola nafkah ganda (beragam pola nafkah berupa pekerjaan lain di luar sektor pertanian, atau menggerakkan tenaga kerja keluarga ikut bekerja di luar pertanian), dan migrasi (keluar dari desa dan mencari pekerjaan di tempat lain).

Frank (1998) menjelaskan lima livelihood assets, yaitu modal alam, modal fisik, modal finansial, modal manusia, dan modal sosial. Pemanfaatan livelihood assets menggambarkan struktur nafkah keluarga petani. Struktur nafkah juga berhubungan dengan sumber pendapatan (on farm, off farm, dan non farm). Struktur nafkah merupakan tingkat pendapatan rumah tangga dari sektor pertanian maupun nonpertanian. 


\section{Metode Penelitian}

Waktu, Lokasi Penelitian, dan Metode Sampling

Penelitian dilakukan di Kecamatan Leitimur Selatan Kota Ambon Provinsi Maluku dengan Negeri Hutumuri dan Negeri Leahari sebagai "negeri" (desa) sampel. Pemilihan negeri sampel ditentukan secara sengaja, karena aktivitas pertanian yang dominan serta didukung oleh aktivitas lainnya. Pertimbangan lainnya adalah keberadaan kegiatan ekonomi dari petani dan nelayan yang sangat menonjol di kedua desa tersebut. Masyarakat di kedua "negeri" melakukan kegiatan yang didominasi oleh usaha pertanian secara umum, walaupun kegiatan ini juga diselingi kegiatan nonpertanian (perikanan). Penelitian dilakukan selama dua bulan, yaitu bulan Juni sampai Juli 2018. Penentuan sampel di kedua negeri dilakukan secara sengaja (purposive) yaitu petani yang rutin melakukan aktivitasnya dalam setahun terakhir. Oleh karena itu, diperoleh 51 petani di Negeri Hutumuri dan 18 petani di Negeri Leahari sehingga jumlah sampel 69 orang. Selain itu, dipilih juga informan kunci dari masing-masing "negeri” yaitu pedagang pengumpul desa untuk mengeksplorasi jawaban responden. Informan kunci dipilih dengan dasar adanya ikatan yang dilakukan dengan petani dan atau nelayan di setiap negeri sampel.

\section{Metode Pengumpulan Data dan Analisis} Data

Data primer dikumpulkan dengan kuesioner yang diberikan kepada responden (Babbie, 2004) dan wawancara mendalam dengan informan kunci (Debus \& Novelli, 1996). Data sekunder diperoleh dengan observasi partisipatif (Robert \& Lincoln, 1994) serta (Babbie, 2004) penulis harus terlibat langsung ke dalam kehidupan sehari-hari masyarakat dengan mendengar dan membedakan apa yang dikatakan dan dilakukan oleh masyarakat sebagai subjek penelitian. Analisis data menggunakan tabulasi sederhana untuk menggambarkan kondisi dan karakteristik lokasi penelitian. Data yang diproses ditampilkan ke dalam tabel dan diagram untuk memudahkan pemaparan kondisi lokasi penelitian.

Hasil Dan Pembahasan

Karakteristik Petani di Kecamatan Leitimur Selatan

\section{Pendidikan}

Pendidikan di wilayah studi berkisar dari pendidikan dasar (Sekolah Dasar) sampai pendidikan menengah (SLTP dan SLTA). Sementara pendidikan tinggi tidak dimiliki oleh satu pun responden. Penyebaran responden menurut pendidikan terlihat pada Tabel 1

Tabel 1. Distribusi Responden Menurut Tingkat Pendidikan Formal

\begin{tabular}{|c|c|c|c|c|c|c|}
\hline \multirow[b]{2}{*}{ Negeri } & \multicolumn{6}{|c|}{ Tingkat Pendidikan Formal } \\
\hline & $\begin{array}{c}\text { Pendidikan } \\
\text { Dasar }\end{array}$ & $\%$ & $\begin{array}{l}\text { Pendidikan } \\
\text { Menengah }\end{array}$ & $\%$ & Jumlah & $\%$ \\
\hline Hutumuri & 20 & 28.9 & 31 & 44.9 & 51 & 73.91 \\
\hline Leihari & 5 & 7.2 & 13 & 19.0 & 18 & 26.09 \\
\hline Total & 25 & 36.1 & 44 & 63.9 & 69 & 100.00 \\
\hline
\end{tabular}

Sumber : Hasil Penelitian (Diolah, 2018) 
Berdasarkan tabel 1 dapat dikatakan bahwa tingkat pendidikan di lokasi penelitian tergolong rendah. Walaupun keberadaan sekolah di Kecamatan Leitimur Selatan sudah tersedia baik pendidikan dasar (Sekolah Dasar) maupun pendidikan menengah (SLTP maupun SLTA). Namun, perlu diperhatikan bahwa keberadaan pendidikan menengah baru muncul setelah tahun 2000. Sebelumnya setelah tamat SLTP, maka siswa melanjutkan SLTA ke luar wilayah kecamatan yaitu ke Desa Lateri maupun Negeri Passo di Kecamatan Baguala. Keadaan ini yang menyebabkan ada siswa yang tidak melanjutkan pendidikan lagi.

\section{Jumlah Anggota Keluarga}

Jumlah anggota keluarga di wilayah studi berkisar dari $\leq 3$ orang sampai $>3$ orang. Penyebaran responden menurut Jumlah Tanggungan dapat dilihat pada Tabel 2

Tabel 2. Distribusi Responden Menurut Jumlah Anggota Keluarga

\begin{tabular}{|c|c|c|c|c|c|c|}
\hline \multirow{2}{*}{ Negeri } & \multicolumn{7}{|c|}{ Jumlah Anggota Keluarga } \\
\cline { 2 - 7 } & $\leq 3$ & $\%$ & $>3$ & $\%$ & Jumlah & $\%$ \\
\hline Hutumuri & 20 & 28.07 & 31 & 44.36 & 51 & 73.91 \\
\hline Leihari & 5 & 7.68 & 13 & 18.58 & 18 & 26.09 \\
\hline Total & 25 & 36.84 & 44 & 63.16 & 69 & 100 \\
\hline
\end{tabular}

Sumber : Hasil Penelitian (Diolah, 2018)

Jumlah anggota keluarga memberikan sumbangan terhadap dua aspek penting dalam rumah tangga. Pertama, memberikan kontribusi terhadap pengelolaan usaha tani sebagai tenaga kerja dalam rumah tangga; dan kedua, menyumbangkan besar konsumsi rumah tangga untuk pangan dan sandang. Kondisi geografis Kecamatan Leirimur Selatan baik di Negeri Hutumuri maupun Negeri Leahari; dari dataran rendah sampai bergunung-gunung dengan wilayah kepemilikan yang umumnya lebih dari satu hektare memerlukan tenaga kerja dalam pemanfaatannnya. Oleh karena itu, keberadaan anggota keluarga menjadi penting sebagai sumber tenaga kerja dalam keluara. Sehingga dapat dilihat bahwa, di kedua desa penelitian jumlah anggota keluarga lebih besar dari tiga orang.

\section{Pekerjaan}

Pekerjaan merupakan ekspresi dari strategi rumah tangga dalam pemenuhan kebutuhannya. Di wilayah studi pekerjaan terdiri dari 3 (tiga) kategori yaitu, petani (P), petani tukang $(\mathrm{PT})$, dan petani nelayan $(\mathrm{PN})$. Penyebaran responden menurut pekerjaan dapat dilihat pada Tabel 3 berikut

Tabel 3. Distribusi Responden Menurut Pekerjaan

\begin{tabular}{|c|c|c|c|c|c|c|c|c|}
\hline \multirow[b]{2}{*}{ Negeri } & \multicolumn{8}{|c|}{ Pekerjaan } \\
\hline & Petani & $\%$ & $\begin{array}{c}\text { Petani } \\
\text { Tukang }\end{array}$ & $\%$ & $\begin{array}{c}\text { Petani } \\
\text { Nelayan }\end{array}$ & $\%$ & Jumlah & $\%$ \\
\hline Hutumuri & 46 & 66.6 & 4 & 5.8 & 1 & 1.5 & 51 & 73.9 \\
\hline Leihari & 9 & 13.0 & 3 & 4.4 & 6 & 8.7 & 18 & 26.1 \\
\hline Total & 55 & 79.6 & 7 & 10.2 & 7 & 10.2 & 69 & 100.0 \\
\hline
\end{tabular}


Tabel 3 menempatkan petani sebagai pekerjaan utama oleh semua responden. Artinya, keberadaan petani di Kecamatan Leitimur Selatan masih menempati posisi penting. Tentunya, tidak lepas dari keberadaan lahan usaha yang memadai, serta didukung produksi yang juga masih memadai untuk memenuhi kebutuhan rumah tangganya. Hal menarik dari tabel 3 yaitu ternyata selain petani ada juga yang turut menggantungkan hidupnya dari usaha perikanan (pertanian secara umum) ataupun tukang (di luar pertanian). Usaha perikanan merupakan bagian dari aktivitas masyarakat pesisir, untuk memenuhi pangan sehari-hari khususnya ikan. Nelayan yang dilakoni masyarakat pesisir merupakan usaha subsisten, walaupun saat hasilnya banyak ada juga yang dijual untuk berbelanja kebutuhan sehari-hari terutama beras dan bumbu dapur yang tidak dimiliki sendiri.

Pekerjaan sampingan sebagai tukang juga memberikan sumbangan bagi pendapatan rumah tangga. Namun, umumnya tidak menjadi pekerjaan utama karena lebih mengarah ke membantu tetangga yang membangun rumah baru ataupun memperbaiki rumah yang mengalami kerusakan (misalnya mengganti atap). Kalaupun ada sumbangan pendapatan, umumnya digunakan juga untuk berbelanja kebutuhan sehari-hari yang utama seperti beras dan bumbu dapur (kecap, bawang, garam) yang tidak dapat diproduksi sendiri.

Tabel 3 juga menunjukkan bahwa sudah ada petani telah mempersiapkan diri dengan alternatif usaha sehingga tidak lagi menggantungkan diri seutuhnya kepada usaha pertanian (on farm). Nelayan menjadi potensi usaha menjanjikan, karena posisi kecamatan Leitimur Selatan di pesisir yang memudahkan aktivitas sebagai nelayan. Hasil data BPS Kota Ambon (2017) juga menunjukkan keberadaan rumah tangga nelayan di Kecamatan Leitimur Selatan, walaupun memiliki nilai produksi perikanan terendah yaitu Rp.200.000.000 per tahun dibandingkan kecamatan lain di Kota Ambon yang berkisar antara Rp.300.000.000500.000.000 per tahun. Kondisi yang sama juga dialami pada usaha ternak yang dijalankan masyarakat. Hasil penelitian juga menunjukkan bahwa semua petani memiliki ternak terutama ayam dan sapi. Namun, belum ada yang khusus menjalankan usaha ternak secara kontinu sebagai sumber pendapatan. Ternak sapi merupakan sumber pendapatan ketika membutuhkan sejumlah uang untuk kebutuhan mendesak, sehingga sapi dapat dijual untuk memenuhinya. Sementara itu ayam umumnya untuk dikonsumsi sendiri, atau juga ada yang dibagikan ke keluarga yang datang berkunjung dari desa lain di Kota Ambon.

\section{Luas Lahan}

Luas lahan merupakan modal manusia dalam melaksanakan usaha taninya. Di wilayah studi luas lahan terdiri dari dari 2 (dua) kategori yaitu, $\leq 1$ Ha dan $>1$ Ha. Pembagian atas dua kategori saja menunjukkan bahwa, keberadaan lahan pertanian di daerah perkotaan semakin terbatas. Penyebaran responden menurut Luas Lahan dapat dilihat pada Tabel 4. 
Tabel 4. Distribusi Responden Menurut Luas Lahan

\begin{tabular}{|c|c|c|c|c|c|c|}
\hline \multirow{2}{*}{ Negeri } & \multicolumn{9}{|c|}{ Luas Lahan (Ha) } & Jumlah & $\%$ \\
\cline { 2 - 8 } & $\leq 1 \mathrm{Ha}$ & $\%$ & $>1 \mathrm{Ha}$ & $\%$ & 51 & 73.91 \\
\hline Hutumuri & 44 & 63.77 & 7 & 10.14 & 18 & 26.09 \\
\hline Leihari & 8 & 11.59 & 10 & 14.50 & 18 & 100.00 \\
\hline Total & 52 & 75.36 & 17 & 24.64 & 69 & 0 \\
\hline
\end{tabular}

Sumber : Hasil Penelitian (Diolah, 2018)

Tabel 4 menunjukkan keberadaan lahan sebagai unsur utama dalam usaha pertanian. Umumnya petani di Leitimur Selatan memiliki luas lahan yang lebih besar dari satu hektar. Namun untuk usaha komoditas cengkeh dan pala, luasan sebagian besar petani berkisar satu hektar. Sebagian besar lahan umumnya ditanami tanaman-buahan, yang hasilnya dimakan sendiri atau berbagi dengan keluarga dari luar desa. Kesulitan petani mengembangkan usaha produktif dengan komoditas cengkeh dan pala, terletak pada kurangnya tenaga kerja serta dibarengi dengan kondisi geografis yang bergunung sehingga menghambat aktivitas produktif petani. Orangtua tidak lagi menggantungkan harapan bahwa anak mereka harus menggantikan sebagai petani, karena umumnya anak-anak setelah lulus SLTA akan melanjutkan pendidikan ke perguruan tinggi. Ada perubahan cara pandang masyarakat bahwa, pendidikan menjadi penting bagi pengembangan sumber daya manusia di masa depan.

Keberadaan lahan yang luas akan tergambar dari penyebaran komoditas yang diusahakan setiap rumah tangga. Umumnya petani di Leitimur Selatan mengusahakan cengkeh dan pala sekitar satu hektare. Sedangkan komoditas buah-buahan, jagung, dan kelapa diusahakan dengan luasan rata-rata di bawah 0,2 hektare. Selain itu, petani juga mengusahakan singkong dan sayuran yang hasilnya untuk konsumsi sendiri. Penjelasan ini terlihat pada Gambar 1.

\section{Gambar 1. Penyebaran Luas Lahan Menurut Komoditas yang Diusahakan}

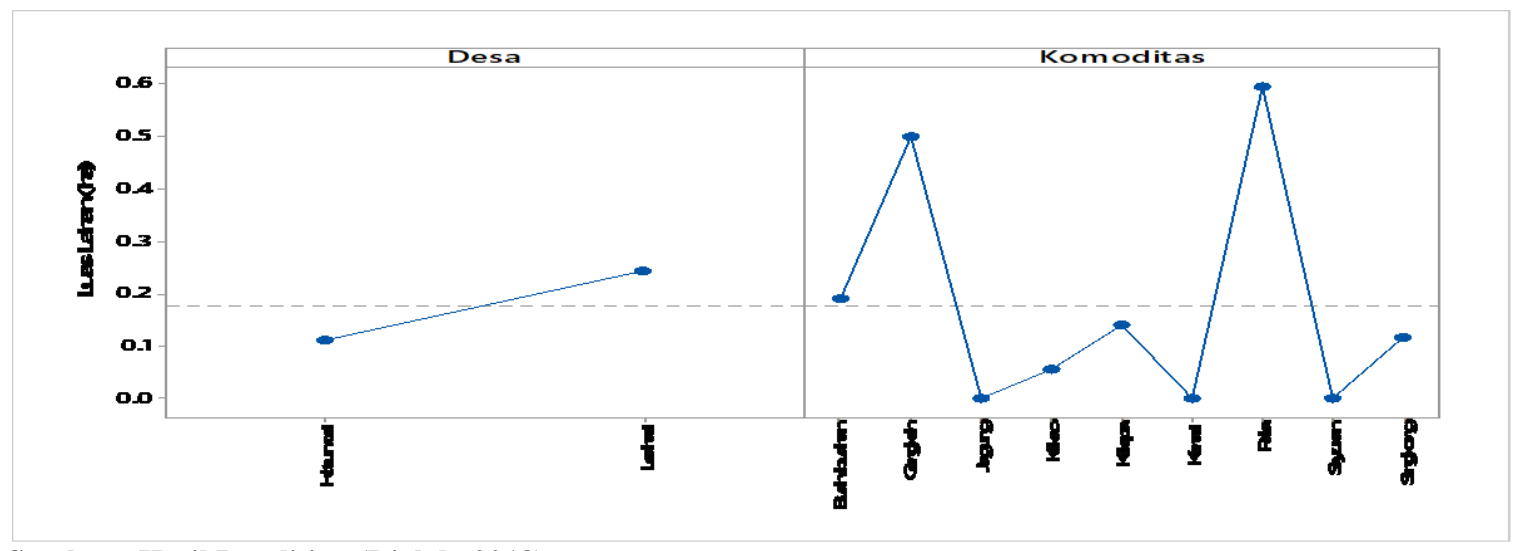

Sumber : Hasil Penelitian (Diolah, 2018) 


\section{Jenis Komoditi Sebagai Sumber Pendapatan Utama}

Jenis komoditi yang diusahakan menunjukkan dua aspek penting dalam kehidupan petani. Pertama, berkaitan dengan pewarisan sistem usaha tani dari generasi

Tabel 5. Distribusi Responden Berdasarkan Jenis Komoditi Sebagai Sumber Pendapatan Utama

\begin{tabular}{|c|c|c|c|c|c|c|c|c|}
\hline \multirow[b]{2}{*}{ Negeri } & \multicolumn{8}{|c|}{ Jenis Komoditi } \\
\hline & Pala & $\%$ & Cengkeh & $\%$ & $\begin{array}{l}\text { Cegkeh } \\
\text { dan Pala }\end{array}$ & $\%$ & Jumlah & $\%$ \\
\hline Hutumuri & 22 & 31.9 & 8 & 11.6 & 21 & 30.4 & 51 & 73.9 \\
\hline Leihari & 3 & 4.3 & 3 & 4.4 & 12 & 17.4 & 18 & 26.1 \\
\hline Total & 25 & 36.2 & 11 & 15.0 & 33 & 47.8 & 69 & 100.0 \\
\hline
\end{tabular}

Sumber : Hasil Penelitian (Diolah, 2018)

Tabel 5 menunjukkan bahwa cengkeh dan pala menjadi komoditas primadona di Kecamatan Leitimur Selatan. Jika merujuk Gambar 1, terlihat perbedaan yang mencolok antara luasan lahan yang ditanami cengkeh dan pala dibandingkan dengan komoditas lainnya termasuk buahan, yang cukup dominan diusaha masyarakat secara turun temurun. Cengkeh sebagai komoditas unggulan sempat dibiarkan tidak terurus saat harga mengalami penurun atau terjun bebas. Sedangkan pala, tetap diusahakan secara kontinu karena harganya lebih stabil. Namun, peremajaan tanaman masih sulit dilakukan karena petani tidak memiliki sistem usaha tani yang memadai sebelumnya; dan kedua, berkaitan dengan pengembangan usaha untuk memenuhi berbagai kebutuhan yang semakin meningkat. Distribusi responden menurut jenis komoditi yang diusahakan, terlihat pada Tabel 5 Jenis Komoditi 
Saat ini harga cengkeh maupun pala cukup baik, mencapai Rp.100.000 per kilogram. Kalau pun mengalami penurunan berkisar antara Rp.70.000-80.000 (Gambar 3). Kondisi harga terutama komoditas cengkeh yang stabil dala $m$ lima tahun terakhir, menyebabkan petani menekuni komoditas cengkeh secara rutin karena memberikan sumbangan penting terhadap pendapatan rumah tangga. Sementara komoditas pala tetap dijaga keberadaannya karena selama ini memiliki harga yang paling stabil sehingga memberikan sumbangan yang rutin terhadap pendapatan rumah tangga. Di tingkat petani, harga Rp.70.000-80.000 sangat menguntungkan dan sebanding dengan energi yang dikeluarkan seiap rumah tangga dalam mengelola usaha tani cangkeh dan pala. Oleh karena itu, petani tetap menjalankan usaha tani cengkeh dan pala karena memberikan sumbangan yang signifikan bagi penerimaan rumah tangga.

Gambar 3. Penyebaran Harga Menurut Komoditas yang Diusahakan

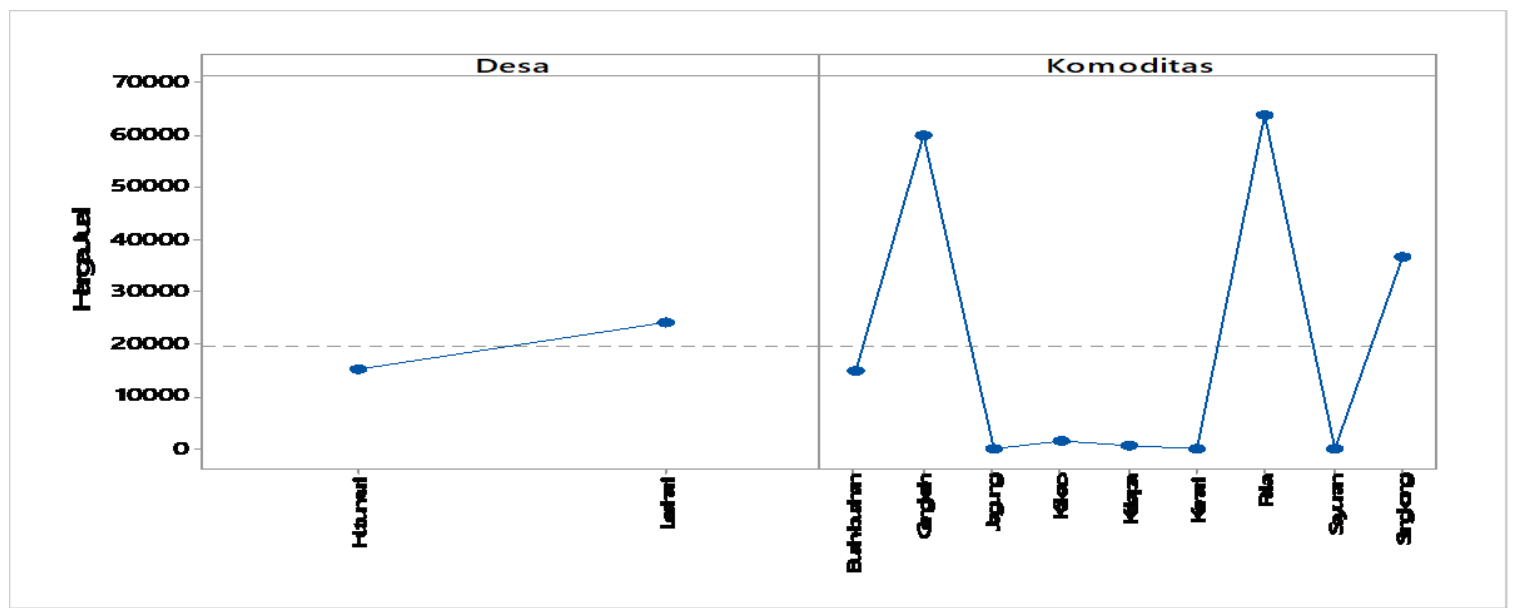

Sumber : Hasil Penelitian (Diolah, 2018)

Pengembangan usaha cengkeh dan pala dominan dilakukan dibandingkan dengan komoditas lainnya. Gambar 4 menunjukkan luas tanam setiap komoditas, yang menempatkan komoditas pala (0.5 hektare) dan cengkeh $(0,4$ hektare). Sementara, komoditas lainnya berada jauh di bawah 0,1 hektare. Komoditas lainnya yang diusahakan petani seperti kelapa, buah-buahan, singkong, dan sayuran lebih cenderung untuk konsumsi sendiri. Kelapa yang pernah diunggulkan setelah diolah menjadi kopra, sekarang ini kurang diminati karena harga kopra yang rendah. Sementara singkong dan sayuran dalam berbagai jenis tetap diusahakan, kerena menjadi komoditas subsisten untuk dikonsumsi sendiri dalam rumah tangga. Kalau pun dijual hanya untuk kebutuhan lokal, baik di Negeri Hutumuri maupun di Negeri Leahari. 
Gambar 4. Penyebaran Luas Tanam Menurut Komoditas yang Diusahakan

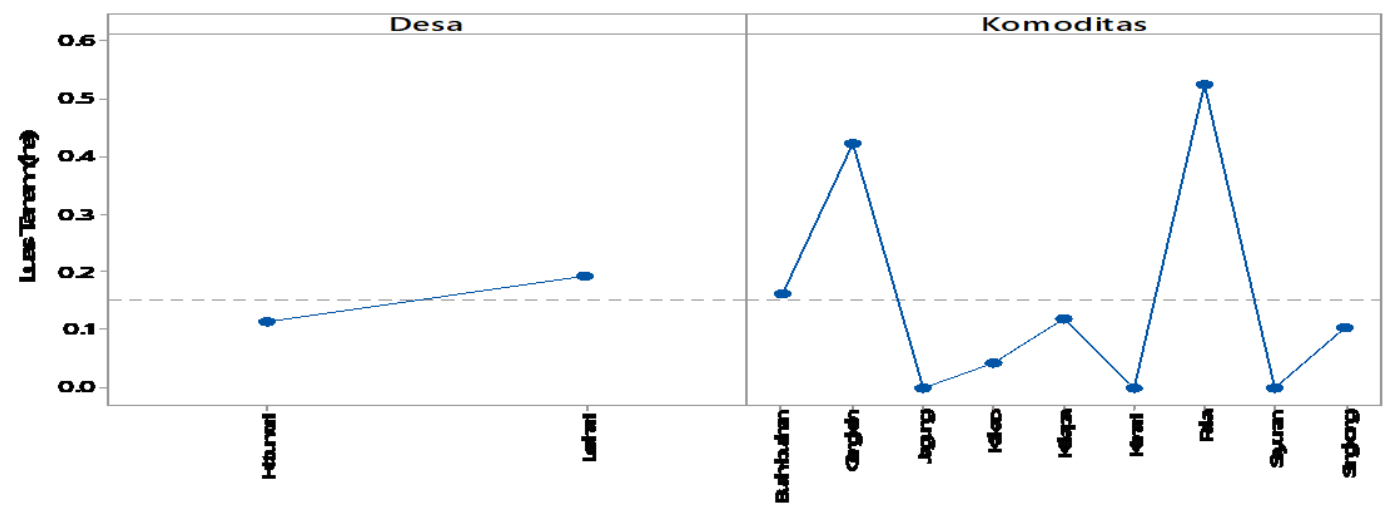

Sumber : Hasil Penelitian (Diolah, 2018)

Komoditas buah-buahan sesuai musimnya juga dapat berkontribusi bagi penerimaan rumah tangga, walaupun dalam jumlah yang kecil. Petani umumnya memiliki komoditas durian sebagai warisan dari orang tuanya, sehingga selalu dipelihara dengan baik sebagai tanda keberadaan kepemilikan lahan (terutama "dusung" yang diwariskan). Komoditas durian menjadi komoditas buahbuahan yang mendominasi lahan "dusung", sehingga saat musim buah-buah maka banyak orang yang datang ke Leitimur Selatan terutama untuk mengkonsumsi durian sebagai buah-buahan unggulan lokal.

Pengembangan usaha tani di lokasi penelitian dapat diukur dari produksi setiap komoditas yang diusahakan. Merujuk gambar
5 , terlihat bahwa umumnya cengkeh dan pala memiliki produksi yang memadai dan merata di kedua negeri. Keberadaan cengkeh dan pala secara merata ini didukung pula oleh adanya harga yang lebih stabil, sehingga kepastian pendapatan petani lebih terjamin. Dengan demikian, petani akan memilih mengembangkan komoditas yang terjamin sumbangan pendapatan bagi rumahtangganya. Selain itu, komoditas buah-buahan dalam berbagai jenis turut memberikan jumlah produksi yang memadai bagi petani. Namun, buah-buahan ini terutama hanya untuk konsumsi sendiri. Kalau pun dijual hanya untuk komoditas tertentu dengan harga yang memadai, seperti komoditas durian.

Gambar 5. Penyebaran Komoditas Menurut Jumlah Produksi
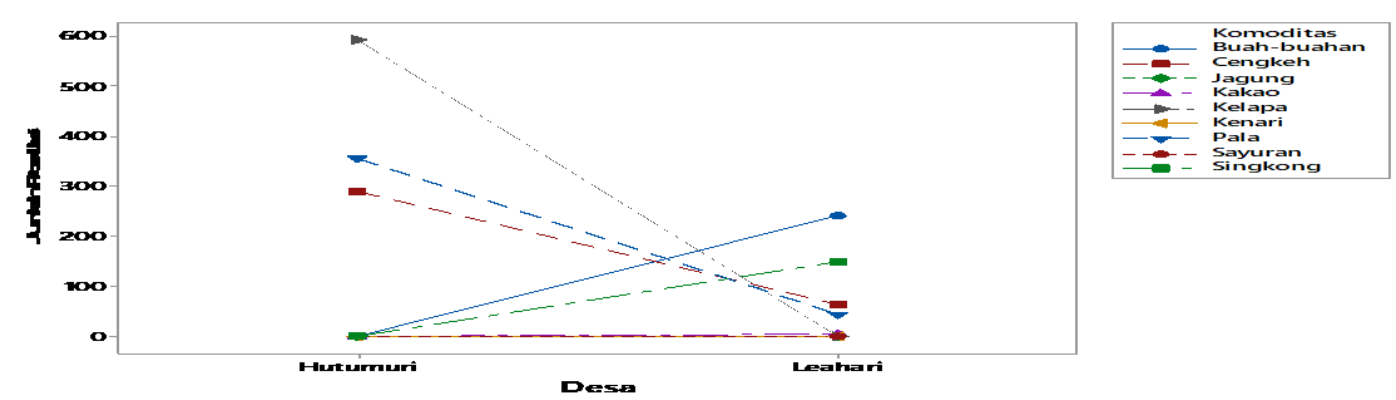

Sumber : Hasil Penelitian (Diolah, 2018) 


\section{Penerimaan}

Penerimaan merupakan ujung dari proses usaha tani. Setelah petani melakukan usaha selama satu musim tanam, maka produksi usaha taninya akan dijual dan menjadi penerimaan rumah tangga. Umumnya dua komoditas penting di lokasi penelitian yaitu cengkeh dan pala, dijual ke pedagang pengumpul desa yang berlokasi pada masingmasing negeri. Distribusi responden menurut penerimaan rumah tangga, terlihat pada Tabel 6

Tabel 6. Distribusi Responden Berdasarkan Pendapatan Rumahtangga

\begin{tabular}{|c|c|c|c|c|c|c|}
\hline \multirow{2}{*}{ Negeri } & \multicolumn{6}{|c|}{ Penerimaan } \\
\hline & $<$ Rp. 2.500 .000 & $\%$ & $\geq$ Rp. 2.500 .000 & $\%$ & Jumlah & $\%$ \\
\hline Hutumuri & 23 & 33.3 & 28 & 40.6 & 51 & 73.9 \\
\hline Leihari & 7 & 10.2 & 11 & 15.9 & 18 & 26.1 \\
\hline Total & 30 & 43.5 & 39 & 56.5 & 69 & 100 \\
\hline
\end{tabular}

Sumber : Hasil Penelitian (Diolah, 2018)

Tabel 6 menjelaskan sebaran penerimaan responden dimana sebagian besar responden memiliki penerimaan di atas Rp.2.500.000. Merujuk jumlah penerimaan rumah tangga, maka sumbangan penting dua komoditas yaitu cengkeh dan pala sangat signifikan. Dominasi cengkeh dan pala ditunjang oleh jumlah produksi dan harga jual yang lebih baik, dibandingkan komoditas lainnya. Walaupun ada komoditas buah-buah dengan jumlah produksi dan luas lahan yang besar, namun karena tidak semua jenis buahbuahan berorientasi komersial sehingga tidak banyak memberikan sumbangan terhadap penerimaan rumah tangga.

Sesuai Keputusan Gubernur Maluku Nomor 254.a Tahun 2017 maka Upah Minimun Regional Propinsi Maluku Tahun 2018 meningkat menjadi Rp. 2.222.220. Terjadi peningkatan UMR sebesar 15 persen. Jika asumsi kenaikan 15 persen tetap berlaku untuk tahun 2019, maka diperkirakan UMR Provinsi Maluku mencapai sekitar Rp.2.500.000. Artinya, pendapatan sebagian besar petani di lokasi penelitian sudah berada di atas upah minimum regional Propinsi Maluku. Selain itu, dapat dikatakan pula bahwa cengkeh dan pala dapat menjadi sumber pendapatan penting dalam rumahtangga petani. Oleh karena itu, upaya untuk mengembangan dan juga meremajakan kedua komoditas ini perlu mendapat perhatian pemerintah. Hasil wawancara mendalam juga menunjukkan bahwa petani cenderung mengupayakan sendiri program peremajaan. Kalaupun ada bantuan pemerintah, jumlahnya sangat terbatas karena harus dibagi ke sejumlah petani di kedua negeri. Dengan demikian, petani juga harus memahami pentingnya peremajaan, sehingga dengan pendapatan yang sudah memadai maka petani dapat mengalokasi sebagian dari pendapatan untuk kepentingan peremajaan cengkeh dan pala. Jika demikian yang dilakukan, maka keberlanjutan kedua komoditas dapat terjaga sekaligus menjadi keberlanjutan pendapatan rumah tangga petani. Gambar 6 secara jelas menunjukkan bahwa sumbangan penerimaan dari cengkeh 
dan pala hampir empat kali lipat dari penerimaan komoditas lainnya.

Gambar 6. Penyebaran Komoditas Menurut Jumlah Penerimaan Petani

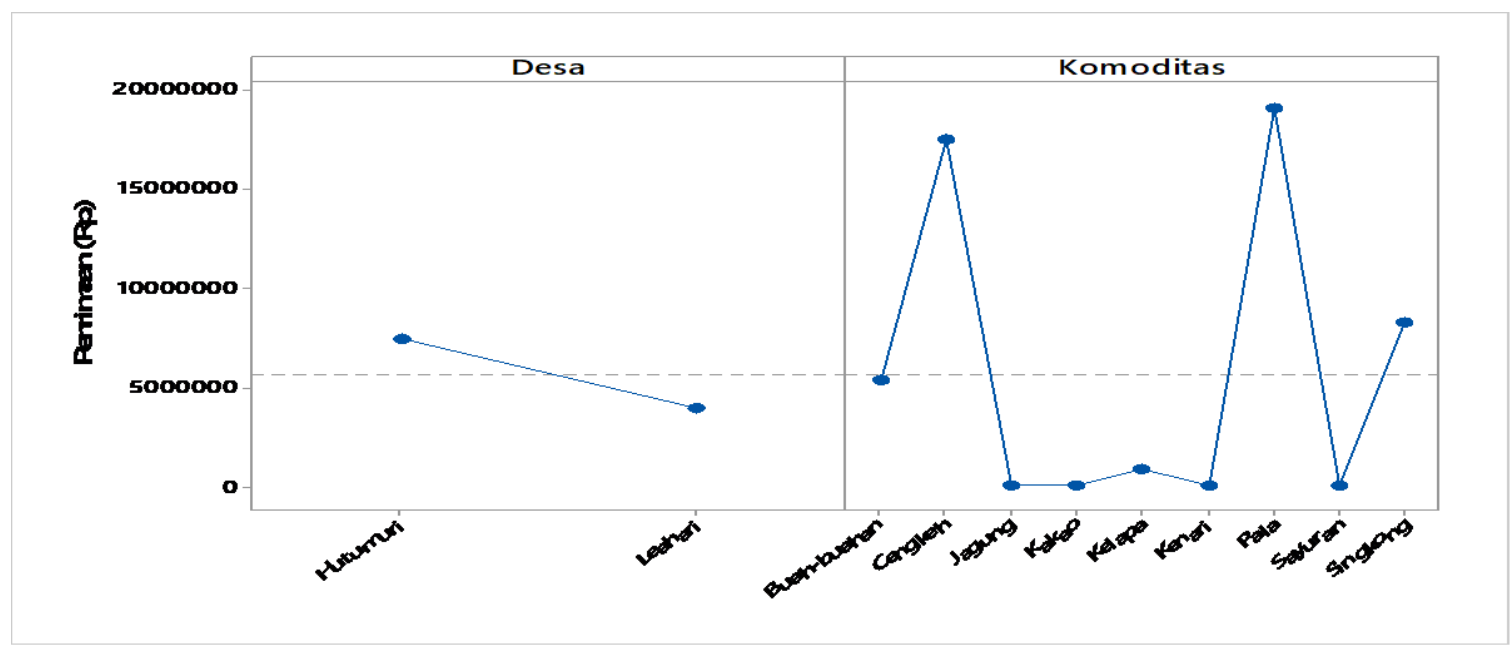

Sumber : Hasil Penelitian (Diolah, 2018)

Keberadaan komoditas lainnya kemudian, dianggap sebagai pelengkap karena gantungan hidup rumah tangga lebih ada pada komoditas cengkeh dan pala. Sementara pengeluaran (biaya produksi) untuk kedua komoditas dapat dikatakan hampir tidak ada, hanya pada biaya transportasi jika rumah petani jauh dari rumah pedagang pengumpul desa. Oleh karena itu, dapat dikatakan biaya produksi berkisar 10 persen dari penerimaan petani. Rendahnya biaya produksi juga menyebabkan pendapatan petani lebih memadai. Rendahnya pengeluaran juga dapat memberikan ruang bagi petani untuk mengalokasi penermaannya bagi upaya peremajaan komoditas pala dan cengkeh. Jika petani sudah memiliki rencana seperti itu maka petani menjadi mandiri dan tidak bergantung lagi pada program pemerintah.
Kalaupun ada bantuan pemerintah maka bantuan tersebut dapat dianggap sebagai stimulus bagi pengembangan usaha tani komoditas pala dan cengkeh

\section{Strategi Nafkah Petani di Kecamatan Leitimur Selatan}

Strategi nafkah yang dikembangkan petani di pesisir Kecamatan Leitimur Selatan dilakukan melalui tiga cara yaitu: mengembangkan usaha taninya dengan komoditas lain di luar perkebunan seperti singkong dan sayuran, mengembangkan usaha taninya dengan aktivitas pertanian dalam arti luas sebagai nelayan, dan menekuni pekerjaan baru di luar pertanian sebagai tukang. Penjelasannya terlihat pada tabel 7 . 
Tabel 7. Distribusi Responden Menurut Strategi Nafkah

\begin{tabular}{|c|c|c|c|c|c|c|c|c|}
\hline \multirow{2}{*}{ Desa } & \multicolumn{2}{|c|}{ Strategi Nafkah } & & \\
\cline { 2 - 9 } & $\begin{array}{c}\text { Pertanian } \\
\text { Dengan } \\
\text { Menambah } \\
\text { Jumlah } \\
\text { Komoditas }\end{array}$ & $\%$ & $\begin{array}{c}\text { Pertanian } \\
\text { Luas }\end{array}$ & $\%$ & $\begin{array}{c}\text { Di Luar } \\
\text { Pertanian }\end{array}$ & $\%$ & Jumlah & $\%$ \\
\hline Hutumuri & 46 & 66.6 & 1 & 1.5 & 4 & 5.8 & 51 & 73.9 \\
\hline Leihari & 9 & 13.0 & 6 & 8.7 & 3 & 4.4 & 18 & 26.1 \\
\hline Total & 55 & 79.6 & 7 & 10.2 & 7 & 10.2 & 69 & 100.0 \\
\hline
\end{tabular}

Sumber : Hasil Penelitian (Diolah, 2018)

Tabel 7 menunjukkan bahwa, pilihan strategi nafkah dilakukan oleh setiap petani dengan menyesuaikan kondisi lingkungan serta kondisi kemampuan masing-masing individu. Pilihan mengembangkan usaha pertanian dilakukan karena, keberadaan lahan usaha yang dimiliki lebih dari 1 (satu) hektar. Oleh karena itu, mereka dapat mengembangkan usahataninya dengan komoditas lainnya terutama singkong dan sayuran. Pilihan komoditas juga disesuaikan dengan kebutuhan pangan, terutama singkong untuk menggantikan beras serta sayuran untuk pelengkap lauk sehari-hari. Saat panen singkong dan sayuran, mereka biasanya menjualnya di depan rumah dan dibeli oleh tetangga sekitarnya.

Selain usaha pertanian maka masyarakat juga berusaha mengembangkan strategi nafkahnya dengan mempertimbangkan potensi lingkungannya. Sebagai masyarakat pesisir maka aktivitas sebagai nelayan menjadi salah satu alternatif usaha. Walaupun memang selama ini, ada juga yang berprofesi ganda sebagai nelayan sesuai kondisi iklim. Namun, aktivitas sebagai nelayan lebih banyak berorientasi subsisten untuk memenuhi kebutuhan pangan. Tujuh responden yang diwawancarai menjelaskan bahwa mereka mulai beraktivitas sebagai nelayan secara bergantian dengan kegiatan pertaniannya. Biasanya pagi mereka ke kebun untuk melakukan pemeliharaan, sedangkan sore sampai malam mereka mencari ikan. Hasil tangkapan menggunakan kail, panah ikan, maupun jaring, jika lebih akan dijual di dalam negeri sendiri. Hasil penjualan dimanfaatkan untuk membeli kebutuhan sehari-hari seperti (beras dan sayuran).

Demikian pula yang dijelaskan tujuh responden yang berstrategi di luar pertanian yaitu sebagai tukang. Umumnya pekerjaan sebagai tukang bergantung permintaan dari tetangga, misalnya dalam memperbaiki rumah atau membuat rumah baru. Walaupun demikian, mereka tetap menyempatkan waktu untuk ke lahan menjalankan fungsi pemeliharaan terhadap tanaman. Ketika ada pekerjaan tukang, maka waktu ke lahan menjadi terbatas. Biasanya dari jam 7-9 pagi atau jam 16-18. Pemilihan waktu disesuaikan dengan tingkat kesibukan aktivitas sebagai tukang. Pendapatan yang diterima sebagai tukang, menurut mereka dapat dimanfaatkan untuk memenuhi kebutuhan sehari-hari yang berkaitan dengan pangan, seperti membeli 
beras dan lauk (ikan dan sayur). Rata-rata penerimaan sebagai tukang berkisar antara Rp.75.000-100.000 untuk pembantu, serta Rp.150.000 sebagai kepala tukang. Namun, karena yang dikerjakan rumah milik tetangga dan kadang-kadang kerabat, biasanya mereka dibayar antara Rp.50.000 untuk pembantu tukang dan Rp.100.000 untuk kepala tukang.

Kenyataan tersebut sejalan dengan pandangan Scoones (1998) pada dua dari tiga bentuk strategi nafkah mulai dari intensifikasi dan ekstensifikasi (memperbanyak komoditas yang diusahakan) dan menerapkan pola nafkah ganda (sebagai nelayan dan tukang). Namun, mereka tidak menjalankan rekayasa spatial atau migrasi karena, keberadaan Kecamatan Leitimur Selatan sudah menjadi bagian dari Kota Ambon sehingga tidak perlu melakukan migrasi sebagai strategi nafkahnya. Jika merujuk pada Frank (1998), maka petani umumnya menjalankan strategi memanfaatkan modal sumberdaya alam (memanfaatkan lahan pertanian dan memanfaatkan pesisir untuk menangkap ikan), serta strategi memanfaatkan modal sumberdaya manusia (memanfaatkan keterampilan sebagai tukang). Hasil penelitian Sopamena (2011) membuktikan bahwa, wanita akan turut serta membentuk berbagai alternatif pekerjaan sebagai bentuk strategi nafkah dalam pemenuhan kebutuhan rumah tangga pascakonflik di pedesaan Pulau Saparua diantaranya dengan berdagang hasil panen komoditas pertanian. Nurwibowo, Rahayu, \& Marwanti (2013) juga menunjukkan bahwa, sumber pendapatan masyarakat ketika menghadapi krisis dibuat beragam, dengan memanfaatkan aktivitas di luar pertanian. Hasil penelitian Sugiharto, Hartoyo, \& Muflikhati (2016) menjelaskan bahwa, masyarakat umumnya menjalankan strategi nafkah campuran dengan bekerja di luar pertanian selain meningkatkan aktivitas pertanian di sawah dan ladang. Kenyataan yang sama juga diungkapkan dari hasil studi Sopamena \& Pattiselanno (2018) bahwa masyarakat pulau kecil di Pulau Selaru memanfaatkan aktvitas pertanian tambahan serta aktivitas pertanian secara umum melalui keterlibatan perempuan yang mencari hasil laut (budidaya rumput laut, mencari teripang, dan lola).

Hal penting yang harus diperhatikan jika merujuk pada penelitian Abdurrahim (2014) yaitu pemerintah harus mengupayakan pengembangan strategi nafkah yang mampu menggerakkan kemampuan masyarakat sehingga tidak lagi mengembangkan usaha yang mengarah pada kegiatan ilegal seperti penggunaan bom untuk menangkap ikan dalam jumlah besar. Kenyataan ini menjadi bahan pertimbangan penting, sehingga upaya memanfaatkan sumberdaya alam secara tidak benar dapat dihindari.

\section{PENUTUP}

\section{Kesimpulan}

1. Petani pesisir memiliki tiga strategi penting dalam memenuhi nafkah rumah tangganya, yaitu dengan mengembangkan potensi sumberdaya alam pertanian melalui menambah jumlah komoditas yang diusahakan; mengembangkan potensi pesisir sebagai tempat mencari ikan; dan mengembangkan potensi sumber daya 
manusia melalui pengembangan usaha di luar pertanian sesuai keterampilan yang dimiliki.

2. Strategi yang selalu didahulukan adalah mengembangkan usaha pertanian dengan menambah jumlah komoditas karena ditunjang potensi kepemilikan lahan, yang didukung budaya pertanian yang sudah lama dipraktekkan masyarakat. Pilihan memanfaatkan perikanan pesisir dengan berbagai bentuk merupakan pilihan strategi kedua karena potensi yang dimiliki wilayah pesisir. Pilihan terakhir yang dilakukan yaitu, mengembangkan potensi sumber daya manusia dengan memanfaatkan keterampilan yang dimiliki masingmasing rumah tangga.

\section{Daftar Pustaka}

Abdurrahim, A. Y. (2014). Strategi Nafkah Ganda "Bentukan" Rumah Tangga Pedesaan Pesisir Di Kabupaten Bintan. Jurnal Sosiologi Reflektif, Vol 9 No 1, $1-22$.

Amalia, R., Dharmawan, A. H., \& Putri, E. I. (2015). Perubahan Lanskap Ekologi Dan Resiliensi Nafkah Rumahtangga Petani Di Sekitar Hutan Di Kalimantan Timur. Sodality, Vol 3 No 3, 121-127.

\section{Saran}

Menyikapi perkembangan strategi nafkah di masyarakat maka pemerintah diharapkan memperhatikan pemanfaatan pesisir sebagai sumber nafkah rumah tangga. Keterdesakan pemenuhan kebutuhan berpotensi untuk mendorong pemanfaatan pesisir dengan cara-cara yang tidak bertanggungjawab misalnya, menggunakan bom dan racun untuk menangkap ikan. Jika demikian yang dilakukan maka akan mengganggu kelestarian lingkungan wilayah pesisir beserta potensi yang ada di dalamnya. Oleh karena itu, pemerintah diharapkan memperhatikan pilihan strategi nafkah dengan sedapat mungkin mengarahkan program pemberdayaan masyarakat melalui pilihan strategi nafkah yang aman baik bagi rumah tangga maupun lingkungannya.

\section{Ucapan Terimakasih}

Penelitian ini dapat terlaksana atas kerjasama dengan Dinas Pertanian dan Tanaman Pangan Kota Ambon melalui Proyek Identifikasi Potensi Perkebunan di Kota Ambon Bulan Mei Sampai Agustus 2018

Babbie, E. (2004). The Practice Of Social Research. Belmont: Thomson / Wadsworth.

Badan Pusat Statistik Kota Ambon. (2018). Kota Ambon Dalam Angka Tahun 2018. Ambon: BPS Kota Ambon.

Budiyanti, I., \& Dharmawan, A. H. (2018). Strategi Nafkah Dan Relasi Sosial Rumahtangga. Jurnal Sains Komunikasi dan Pengembangan Masyarakat [JSKPM], Vol. 2 (1), 105122. 
Debus, M., \& Novelli, P. (1996). Methodological Review: A Handbook for Excellence in Focus Group Research. Washington: Academy for Educational Development.

Frank, E. (1998). Rural livelihood diversity in developing country. London: Oxford University Press.

Fridayanti, N., \& Dharmawan, A. H. (2013). Analisis Struktur Dan Strategi Nafkah Rumahtangga Petani Sekitar Kawasan Hutan Konservasi Di Desa Cipeuteuy, Kabupaten Sukabumi. Sodality, Vol 7 No 1, 29-41.

Hidayati, H. N., Nurdin, I. P., Budiandrian, B., Attamimi, G. R., \& Rohayati. (2015). Strategi Nafkah Penambang Pasir Dusun Citerate Desa Ujung Genteng Kabupaten Sukabumi Provinsi Jawa Barat. Sodality, Vol 3 No 3, 115-120.

Mardyaningsih, D. I., Dharmawan, A. H., \& Tonny, F. (2014). Dinamika Sistem Penghidupan Masyarakat Tani Tradisional dan Modern di Jawa Barat. Sodality, Vol 4 No 1, 115-145.

Niswah, Z. K., \& Adiwibowo, S. (2013). Strategi Nafkah Masyarakat Adat Kasepuhan Sinar Resmi Di Taman Nasional Gunung Halimun Salak. Sodality, Vol 7 No 1, 91-98.

Nurwibowo, M., Rahayu, E. S., \& Marwanti, S. (2013). Struktur Dan Distribusi Pendapatan Rumah Tangga Serta Strategi Kebijakan Peningkatan Kesejahteraan Petani Jagung Di Lahan Perhutani Di Kecamatan Tanggungharjo Kabupaten Grobogan Provinsi Jawa Tengah. Agribusiness Review, Vol 1, No 1, 21-32.

Pattiselanno, A. E., Tuhumury, M. T., Wenno, N. F., \& Sopamena, J. F. (2017). Collaborative Livelihood Strategy: A Reflection of Social Network in Economic Activity (Case Study in Small Islands, Maluku Province, Indonesian). International Journal of
Environment, Agriculture and Biotechnology (IJEAB), Vol-2, Issue-5, 2466-2472.

Robert, D., \& Lincoln, J. (1994). Handbook of Qualitative Research. Thousand Oaks : Sage Publications.

Saraswati, Y., \& Dharmawan, A. H. (2014). Resiliensi Nafkah Rumahtangga Petani Hutan Rakyat Di Kecamatan Giriwoyo, Wonogiri. Sodality, Vol 8 No 1, 72-84.

Scoones, I. (1998). Sustainable rural livelihood: A Framework for Analysis. Brighton: Institute of Development Studies, University of Sussex.

Sembiring, S. T. (2014). Resiliensi Nafkah Rumahtangga Petani Di Kawasan Rawan Bencana Rob Kecamatan Kampung Laut, Kabupaten Cilacap. Sodality, Vol 8 No 1, 33-46.

Sopamena, J. F. (2011). Wanita dan Strategi Nafkah Rumahtangga (Kasus di Desa Pia Kecamatan Saparua Kabupaten Maluku Tengah). Komunitas, Vol 1 No 2, 17-26.

Sopamena, J. F., \& Pattiselanno, A. E. (2018). Tnyafar: Women, Livelihoods Strategy in Selaru Island, West Southeast Maluku District. International Journal of Environment, Agriculture and Biotechnology (IJEAB), Vol -3, Issue5, 1685-1690.

Sugiharto, A., Hartoyo, \& Muflikhati, I. (2016). Strategi Nafkah Dan Kesejahteraan Keluarga Pada Keluarga Petani Tadah Hujan. Jur. Ilm. Kel. \& Kons., Vol. 9, No.1, 33-42 .

Tridakusumah, A. C., Elfina, M., Mardiyaningsih, D. I., Pioke, J., \& Bumulo, S. (2015). Pola Adaptasi Ekologi Dan Strategi Nafkah Rumahtangga Di Desa Pangumbahan. Sodality, Vol 3 No 3, 85-90.

Widodo, S. (2009). Strategi Nafkah Rumah Tangga Nelayan. Kelautan, Volume 2, No.2 Oktober 2009, 150-157 
August, Edizon, Junianita 